\title{
ANTIQUARIANISM AS GENEALOGY: ARNALDO MOMIGLIANO'S METHOD
}

\author{
REBECCA GOULD
}

\begin{abstract}
This essay uses Arnaldo Momigliano's genealogy of antiquarianism and historiography to propose a new method for engaging the past. Momigliano traced antiquarianism from its advent in ancient Greece and later growth in Rome to its early modern efflorescence, its usurpation by history, and its transformation into anthropology and sociology in late modernity. Antiquarianism performed for Momigliano the work of excavating past archives while infusing historiographical inquiry with a much-needed dose of contingency. This essay aims to advance our understanding of the mutual imbrications of antiquarian methods with modern conceptions of history, while also suggesting how antiquarianism can generate alternatives to historical inquiry.
\end{abstract}

Keywords: antiquarianism, genealogy, historiography, disciplinarity, Herodotus, contingency, doubt, certainty

Among the intellectual giants of the twentieth century, Arnaldo Momigliano (1908-1987) will be remembered as the historian who historicized history. In the aftermath of the copious festschrifts, memorial volumes, and critical studies that have appeared during the quarter-century following Momigliano's death, this Italian intellectual is gradually emerging as the twentieth century's most important scholar in two fields that rarely converge in the same intellect: ancient Roman history and the modern historiographical method. Like his near contemporary, Michel Foucault (1926-1984), for whom Momigliano expressed guarded admiration on many occasions, Momigliano bequeathed to us a genealogy of humanistic inquiry extending from antiquity to the present. Momigliano's genealogy culminates in an empirically dense and theoretically ambitious vision concerning the mutual imbrications of history, antiquarianism, and the social sciences, from antiquity to the present.

Momigliano's writings plot an itinerary for human knowledge as comprehensive and richly suggestive as Foucault's institutional genealogies of the asylum, the clinic, and the prison, as well as his disciplinary genealogy of philology, biology, and political economy. ${ }^{2}$ But whereas Foucauldian genealogies expose power

1. I would like to thank my research assistant Joshua Wong (Yale-NUS College) for his assistance with editing this essay.

2. Michel Foucault, Folie et déraison: Histoire de la folie à l'âge classique (Paris: Plon, 1961); Naissance de la clinique: Une archéologie du regard medical (Paris: Presses universitaires de France, 1963); Les mots et les choses (Paris: Gallimard, 1966); Surveiller et punir: Naissance de la prison (Paris: Gallimard, 1975). 
in the process of its emergence from various fields of knowledge, Momiglianian genealogies register the traces of the past on the present. Further, Momigliano elucidates the specificity of history by comparing it with disciplines that engage the past without self-identifying as history. ${ }^{3}$ This essay examines the most suggestive knowledge form that falls under this rubric, which Momigliano termed "antiquarian knowledge."

The antiquarian concept usefully identifies a form of knowledge not always registered within conventional history, particularly in its nineteenth- and twentieth-century iterations. Momigliano was hardly the first scholar to consider antiquarianism as a form of knowledge unto itself. Prior to Momigliano's intervention, however, no scholar had studied antiquarianism with reference to the sea changes introduced by modern disciplinary knowledge, nor had ancient antiquarianism been considered in relation to modern knowledge forms such as history. In these respects, Momigliano's interventions were new. In order to better discern the newness of Momigliano's concept of antiquarianism, we must begin with a genealogy of the genealogical principle from which antiquarianism derives. We should also consider the framing of the genealogical method by the thinker whom Momigliano recognized as its most influential modern practitioner, Michel Foucault.

\section{ANTIQUARIAN GENEALOGY}

In different ways and for different reasons, genealogy preoccupied both Momigliano and Foucault throughout their writing careers. Often this preoccupation was accompanied by an engagement with genealogy's preferred medium, archeology. Archeology meant different things for Foucault and Momigliano, but the term surfaces frequently in both oeuvres as a concrete manifestation of the genealogical method, uniting the otherwise seemingly disparate pairing of an ancient historian and a theorist of modern sovereign power.

When asked to distinguish between archeology and genealogy, Foucault described archeology as the "aim" of his analysis and genealogy as its "material and methodological framework." Whereas Foucauldian inquiry is genealogical in its aims and archeological in its method, Momiglianian inquiry is historical in its aims and antiquarian in its methods. To distinguish between these two modes of inquiry is to conceive the reverberations of history beyond a specific discipline while narrating the emergence of the historical method as a disciplinary paradigm. In the context of this essay, that means tracing the modern discipline of history to its origins in post-eighteenth-century Europe.

In his classic essay "Nietzsche, la généalogie, l'histoire" (1971), Foucault isolates three genealogical registers that help to elucidate Momiglianian antiquari-

3. Momigliano and Foucault also shared a common engagement with the problem of parrhesia (free speech). Momigliano's classic contribution to this subject is "Liberty and Peace in the Ancient World," in Nono contributo alla storia degli studi classici e del mondo antico (Rome: Storia e Letteratura, 1992), 483-501; Foucault's lectures on parrhesia, delivered at the University of California, Berkeley in 1983, are collected in Fearless Speech (Los Angeles: Semiotexte, 2001).

4. Michel Foucault, "Foucault replies to questions from the audience at Berkeley's History Department in 1983," Audio file transcribed by Arianna Bove at http://www.generation-online.org/p/fpfoucault4.htm (accessed January 26, 2014). 
anism. These three registers are methodological, substantive, and metaphysical. ${ }^{5}$ The first register pertains to the method that drives antiquarian inquiry. Although he explicitly states that genealogy does not oppose itself to history, Foucaultwithout invoking Momiglianian antiquarianism - distinguishes between the subject proper to historical inquiry and the subject proper to antiquarian genealogy. Genealogy, writes Foucault, records "events in their singularity [la singularité des événements] outside any totalizing finality [hors de toute finalité monotone]. Like antiquarianism, genealogy flourishes in realms of minute knowledge [la minutie du savoir] and entails vast accumulations of source material [un grand nombre de matériaux entassés]. ${ }^{6}$

Genealogy's second register pertains to its medium. Genealogy's monuments are constructed, like antiquarian knowledge, from "petites vérités" that bear an aura of insignificance, but through methods that are no less rigorous for their seeming obscurity than the seemingly more objective discourses of history. The third register of Foucault's discussion pertains to genealogy's resistance to metaphysics. Foucault insists that genealogy cannot result from "large, well-meaning errors [grandes erreurs bienfaisantes]." Foucault concludes with a perhaps unintended allusion to the antiquarian method: genealogy requires "a certain eagerness [acharnement] for erudition."7 Foucault presents these formulations as variations on a theme that originates in Nietzsche's genealogical trilogy-Die fröhliche Wissenschaft, Zur Genealogie der Moral, and Menschliches, Allzumenschliches-although the French thinker is even more invested than Nietzsche in disciplinary methodologies.

A fourth dimension of Foucauldian genealogy also deserves attention in this context: namely, genealogy's relation to silence, and the political implications thereof. Foucault imputes to genealogy a burden that can be glossed politically, as the art and science of excavating "the silences, the world of memory, of itinerant, barely surviving groups, the places of exclusion and invisibility." ${ }^{8}$ Without foreclosing a wide range of possible and even contradictory political deployments, it may be observed that Momiglianian antiquarianism parallels Foucauldian genealogy in its equally profound concern with silences, memories, and with "places of exclusion and invisibility." Whereas Foucault sought to write a counter-history of subjugation, silence acquires life in Momigliano's method through the historian's engagement with what he famously termed "alien wisdom": ancient Jewish, Egyptian, and Iranian knowledge as viewed through the lens of post-classical Hellenism. ${ }^{9}$ Momigliano's investigations of alien wisdom are the empirical counterpart to his theoretical engagement with nonhistorical methods for excavating the past.

The genealogical principle is enshrined, among other places in Momigliano's oeuvre, in his remarks on Foucault. Although he did not subject Foucault's work

5. Michel Foucault, "Nietzsche, la généalogie, l’histoire," Dits et écrits (Paris: Gallimard, 1994), II, 136-156. This essay originally appeared in a festschrift to the French Hegelian Jean Hyppolite.

6. Ibid., 136 .

7. Ibid., 137.

8. The citation is from Edward Said, "The Return to Philology," in Humanism and Democratic Criticism (New York: Columbia University Press, 2003), 81, referencing his conception of "humanist philology."

9. Arnaldo Momigliano, Alien Wisdom: The Limits of Hellenization (Cambridge, UK: Cambridge University Press, 1990). 
to extended examination in his published writings, Momigliano did attest on three memorable occasions to the significance of the Foucauldian genealogical method for his understanding of contemporary historiography. Each statement is worth considering closely, inasmuch as Momigliano's engagement with Foucault parallels - in certain aspects anticipating and in other respects reflecting-his conception of the antiquarian imagination.

Momigliano's first comment on Foucault occurs in an essay on contemporary British intellectual history that he self-consciously frames from the perspective of his native Piedmont. "The traditional oppositions," Momigliano writes, "between ideas and institutions, between ideology and society, or, quite simply, between beliefs and facts have become far too crude to define the new levels of exploration" in contemporary intellectual history..$^{10}$ Momigliano adds that this transformation in modern knowledge is most powerfully registered by "the astute Michel Foucault" who has "put across his new 'archéologie du savoir' to replace 'l'histoire des idées'." Paraphrasing Foucault's French, Momigliano adds that Foucault aimed to free the history of thought from its transcendental subjugation (affranchir l'histoire de la pensée de sa sujéction transcendentale). This characterization of Foucault by Momigliano highlights the two thinkers' common interest in change over the longue durée and with specific reference to the organization of disciplinary knowledge.

Momigliano's second allusion to Foucault occurs in an Italian article intended to introduce developments in European historiography during the 1960s and 1970 s to an Italian readership. Now writing specifically for an Italian audience, Momigliano more ardently appropriates Foucault for his own discipline, history, which means in effect assimilating Foucauldian genealogy to his antiquarian method. Momigliano states that "If M. Foucault appears in theory as a negator of the historical movement [un negatore del movimento storico], his historical works are nonetheless infused with an original and profound awareness of intellectual changes [cambiamenti intellettuali]."11

Returning to British intellectual history, in his third pronouncement on the French intellectual, Momigliano compares Foucault to Herodotus in a late essay on the ancient Greek historian who was his most important model for his own historiographical craft. ${ }^{12}$ "Perhaps to connect the name Herodotus with that of Michel Foucault," Momigliano writes, "who until yesterday was our most original among our contemporary historians, is the best way to indicate what the Herodotian tradition can still produce." ${ }^{13}$ Measured against Momigliano's profound investment in Herodotus's legacy, detailed throughout the remainder of this essay, the comparison of Foucault to Herodotus appears as the greatest

10. Momigliano, "A Piedmontese View of the History of Ideas," Essays in Ancient and Modern Historiography (Chicago: University of Chicago Press, 2012), 5.

11. Momigliano, "La storiografia del quindicennio 1961-1976," Sesto contributo alla storia degli studi classici e del e del mondo antico (Rome: Storia e Letteratura, 1980), 390.

12. Although Thucydides' historiographical method was the subject of Momigliano's first major scholarly publication, published at the age of twenty-two ("La Composizione della storia di Tucidide," Memoria della Reale Accademia delle Scienze ditorino 2, no. 67 [1930], 1-48), as discussed below, the later stages of his scholarly career evince a much closer affinity for Herodotus.

13. Momigliano, Ottavo contributo alla storia (Rome: Storia e Letteratura, 1987), 23. 
tribute that could have emerged from Momigliano's pen. This comparison also usefully sets the stage for Momigliano's genealogy of antiquarian knowledge.

Admittedly, the ancient historian's engagement with history differed sharply from the French theorist who questioned the historical enterprise as such, just as Momigliano's aspirations diverged from those of Hayden White, whose Metahistory (1973) proposed reading historical discourse tropologically, or as Momigliano himself critically phrased it, to reduce history to rhetoric. ${ }^{14}$ (At the same time, Momigliano referred to White as a "friend" and was keen to engage with his claims concerning the frailty of historical knowledge.) As Peter Miller notes in his important study of Momigliano's antiquarian method, the historian of antiquity does not participate in the "Heideggerian critique of historicity, upon which Foucault rests" and which questions the "very foundation in subjectivity that was presupposed by the entire Western historical tradition." 15 Much of Momigliano's work in fact rejected precisely the forms of skepticism that underwrote the Foucauldian project, and which for Momigliano were epitomized by early modern Pyrrhonists such as Pierre Bayle, Daniel Huet, and La Mothe de Vayer, who attacked both "traditional historical teaching" and "traditional religious beliefs." 16

Their epistemological divergences notwithstanding, the projects on which Foucault and Momigliano were embarked during the most fruitful periods of their lives - genealogy in the first instance and antiquarianism in the secondshare an ethical orientation, an intellectual ambition, and a political goal of fostering appreciation for cultural and conceptual difference. In keeping with their shared commitment to assisting in the development and recognition of alternative knowledge forms, both thinkers transformed, and continue to transform, the methodologies that structure the humanities and social sciences. Their excavations of past textual archives call on us, their posthumous audience, to revise regnant disciplinary distinctions when they cease to generate new kinds of knowledge. In equally compelling if divergent ways, both Momigliano and Foucault crafted knowledge forms that engaged deeply with the past without naturalizing the divisions of intellectual labor-between past and present, fact and fiction, linearity and synchronicity - that structure and arguably constrain modern historiographical inquiry.

\section{MOMIGLIANIAN ANTIQUARIANISM}

Antiquarians from the sixth century BCE onwards have found ways to elucidate the documentary records inscribed onto epigraphy, coins, and other material remnants from times past, but a sustained historical account of the actual work done

14. Arnaldo Momigliano, "La retorica della storia e la storia della retorica," Sui fondamenti delta storia antica (Turin: Einaudi, 1984). In Figural Realism: Studies in the Mimesis Effect (Baltimore: Johns Hopkins University Press, 2000), White called Momigliano's polemic “basically hostile but fair" (180, n. 20).

15. Peter N. Miller, "Momigliano, Benjamin, and Antiquarianism after the Crisis of Historicism," in Momigliano and Antiquarianism: Foundations of the Modern Cultural Sciences, ed. Peter N. Miller (Toronto: University of Toronto Press, 2007), 364.

16. Momigliano, "Ancient History and the Antiquarian," Journal of the Warburg and Courtauld Institutes 13 (1950), 296 (= Contributo alla storia degli studi classici [Rome: Storia e Letteratura, 1955], 81.) 
by antiquarianism across the disciplines had to wait until the twentieth century. The inaugural manifesto of this modern approach to antiquarian knowledge is Momigliano's 1950 article, "Ancient History and the Antiquarian," published in the journal of the Warburg Institute, Momigliano's institutional home after he was compelled to flee Italy in the years leading up to World War II. Formally part of the University of London, the Warburg Institute was Momigliano's intellectual and institutional haven during what his student Anthony Grafton has termed Momigliano's "middle period," sandwiched between his early empirical studies of Roman history and the interrogations into the meaning and construction of historiographical knowledge of his final decades. ${ }^{17}$ "Ancient History and the Antiquarian" also contains ab ovo ideas that were later reworked for the 1962 Sather lectures, delivered at the University of California, Berkeley, and published posthumously only in 1990, under the title The Classical Foundations of Modern Historiography. ${ }^{18}$

Already in his 1950 article, Momigliano engaged two disciplinary trajectories to account for ancient and modern ways of narrating and recording the past. Building on the Saussurean distinction between synchrony and diachrony, Momigliano proposed that ancient antiquarianism, for which the loci classici were Herodotus's Histories and Varro's now-lost Antiquitates rerum divinarum (c. $47 \mathrm{BCE}$ ), was preoccupied with change according to a synchronic axis. ${ }^{19}$ In Momigliano's reading, Roman antiquarianism was more politically inflected than its Greek counterpart, and thus more "directly relevant to political life than any Hellenistic treatise on the antiquities of a Greek city." ${ }^{20}$ Due to the vertical temporality intrinsic to the antiquarian method, both Greek and Roman antiquarians were more likely to engage with the ancient than with the recent past. Antiquarians were also more likely to borrow from propagators of myth and were more inclined toward philosophy than were their historian counterparts. Thucydides' dismissal of the Homeric epics as valid sources for historical knowledge, and of Homer, whose authority was "not equal to those of our own day" and who, as a poet, was "expected to exaggerate," is one of the earliest extant juxtapositions

17. Anthony Grafton, "Momigliano's Method and the Warburg Institute: Studies in his Middle Period," in Miller, ed., Momigliano and Antiquarianism, 97-126. For more on this period in Momigliano's intellectual trajectory, see Grafton, "Momigliano at the Warburg: The Origins of a Style," American Scholar 73, no. 4 (2004), 129-132; Michael Crawford, "L'insegnamento di Arnaldo Momigliano in Gran Bretagna," in Omaggio ad Arnaldo Momigliano: Storia e storiografia sul mondo antico, ed. Lellia Cracco Ruggini (Como: Biblioteca di Athenaeum, 1989), 27-41. The Warburg Institute also hosted a conference series during 2009 entitled "The Legacy of Arnaldo Momigliano."

18. Momigliano, The Classical Foundations of Modern Historiography, ed. Riccardo Di Donato (Berkeley: University of California Press, 1990).

19. For the synchrony/diachrony distinction (which does not appear in the 1950 article, but does in Momigliano's later work, and which may have derived only indirectly from Saussure), see Ferdinand de Saussure, Course in General Linguistics, transl. Wade Baskin, ed. Perry Meisel and Haun Saussy (New York: Columbia University Press, 2013), 81, 89-98. Herodotus figures much more fully as an antiquarian in Momigliano's later work (for example, Classical Foundations) and is not discussed in this capacity in the 1950 article.

20. Momigliano, "Ancient History and the Antiquarian," 289. For an illuminating study of Varro's antiquarian mind that profits from Momigliano's intervention, see Joseph McAlhany, "Language, Truth, and Illogic in the Writings of Varro" (PhD diss., Columbia University, 2003). 
between antiquarian and historical knowledge. ${ }^{21}$ Notably, Thucydides makes his preference clear in the act of juxtaposing these forms of knowledge.

The historian/antiquarian distinction is further elucidated by Herodotus's engagement with Homer. Herodotus also polemicized with Homer over his treatment of Helen, and specifically criticized his predecessor for excluding the Egyptian version of the Helen story from his narrative, but this critique was directed to a fellow traveler within a shared intellectual method. Homer may not have been a historian for Herodotus (indeed the word had yet to acquire currency during Herodotus's lifetime), but he was certainly a storyteller in the Benjaminian sense. Herodotus even accounted for Homer's exclusions in terms of the formal injunctions intrinsic to his chosen genre. Homer, reasons Herodotus, knew of the Egyptian story concerning Helen's sojourn in Egypt, but excluded it from the Iliad, "since it was not as appropriate for epic composition" as the story he actually used.$^{22}$ Yet even as Herodotus criticized certain of Homer's poetic choices, it is notable that his style and sense of vocation was shaped above all by Homer's poetry, as well as by that of fellow antiquarians from a few generations prior, such as Hecataeus of Miletus (fl. $500 \mathrm{BCE}$ ) ${ }^{23}$ This intermingling of poetry and history in Herodotus's work had already been recognized in antiquity by the author of On the Sublime, who described Herodotus as "the most Homeric" (13.3) due to his style and language.

Also indicative of the distance between the historian and antiquarian in antiquity is the fact that whereas Thucydides' military history was confined to the lives of the inhabitants of Hellas, Herodotus's curiosity took him far beyond the boundaries of the Peloponnesian peninsula, partly in consequence of which his influence was less extensive than that of his historian rival. Herodotus narrates the past as a global - and not specifically Greek - enterprise from the very opening of his narrative. Herodotus explains that he writes so that "the great and wonderful deeds - some brought forth by the Hellenes, others by the barbarians-[would] not go unsung" (1.1). For Thucydides, the narration of events in time is circumscribed by the interests of specific polities, primarily Sparta, Athens, and other Peloponnesian city-states. By contrast, the Herodotian concept of inquiry/history is autonomous from any imperative, or even desire, to glorify a specific political regime. Consider Herodotus's critique of Hellenic accounts of their gods in his ethnography of Egypt (2.45). This distance is evident in the title Herodotus gave to his opus, istoria (ioto@í $\alpha$ ), a noun that at the time of its composition meant simply "inquiry." ${ }^{24}$ When Herodotus writes of the deeds of kings, it is in order to enhance his text with the narrative appeal of their lives, and

21. Thucydides, History of the Peloponnesian Wars, transl. Benjamin Jowett (Oxford: Clarendon Press, 1900), 8.

22. The Landmark Herodotus, ed. Robert B. Strassler, transl. Andrea Purvis (New York: Anchor Books, 2007), 1.116. All future citations from Herodotus are from this edition, and given parenthetically, with reference made only to book and chapter, not to page number.

23. For Herodotus's debt to Homer, see David Asheri, A Commentary on Herodotus, Books 1-4, ed. Oswyn Murray and Alfonso Moreno (Oxford: Oxford University Press, 2008), 49. Momigliano discusses Hecataeus in Classical Foundations, 9, 15.

24. For this signification, see, among others, Peter G. Bietenholz, Historia and Fabula: Myths and Legends in Historical Thought from Antiquity to the Modern Age (Leiden: Brill, 1994), 24. 
to buttress his account with "great and wonderful deeds" (1.1), rather than due to any strategic or political mandate.

As Momigliano reflected on frequently over the course of his career, and particularly during the years when he was most intensively embarked on the study of antiquarianism, historians of antiquity regarded the History of the Peloponnesian War as the founding text of their discipline and by comparison discounted the Herodotian legacy. ${ }^{25}$ Thus, whereas we have an essay from Plutarch's pen entitled "On the Malice of Herodotus," there is no comparable attempt to discredit Thucydides. Herodotus's synchronic evocation of the past-his willingness to situate his narrative self within the stream of events, and to equalize his temporal location with the other temporalities operating in his narrative-precluded his inclusion in mainstream historiography. As Momigliano recounts, "the very fact that each translator and editor of Herodotus found it necessary to defend him against Thucydides and Plutarch shows that at the beginning of the sixteenth century [Herodotus's] reputation was, generally speaking, quite bad." ${ }^{26}$

The most decisive marker of a change in attitude was the vindication of his work by Heinricus Stephanus, whose Apologia pro Herodoto was published in 1566. As Momigliano notes, Stephanus's work appeared the same year that the political theorist Jean Bodin published his comprehensive exposition of the historical method, Methodus ad facilam historiarum cognitionem (Method for the Easy Comprehension of History), which reframed the discipline of history in unprecedentedly global terms. Whether Bodin was more influenced by the antiquarian or the historical strain of reflection on the past in this endeavor remains an open question. More certain is that Stephanus's account of Herodotus's comparative method is "a work of decisive importance in European historiography" that extended the very scope of possible ways of reflecting on the past. ${ }^{27}$

Like Herodotus, Thucydides recognized the pastness of the past, but in the latter case, the past/present distinction underwrote a one-sided relation. In Thucydides, the historian is severed from his material by virtue of his discursive position. In Herodotus, the "inquirer" (to deploy ioto@í $\alpha$ in its literal meaning) affiliates so closely with his subjects, including "barbarian" peoples such as the Persians and Egyptians, that he projects the names of Greek gods onto their deities (see $1.131 ; 2.41 ; 2.46)$. Thucydides was the ideal predecessor for historians of later eras, such as Ranke, who regarded it as their task to make the past cohere through archival research that drove, "like a tank, on indestructible documentary treads." ${ }^{28}$ By contrast, Herodotus was the ideal predecessor for antiquarians like Momigliano who regarded it as their task to narrate the past so compellingly that the narrator's self could merge with his subject. The two roles were not mutually exclusive in all cases, and indeed Momigliano arguably came closer than any other modern thinker to merging the opposed poles of antiquarian and historical

25. See Arnaldo Momigliano, "Erodoto e la storiografia moderna," Aevum 31 (1957), 74-84.

26. Arnaldo Momigliano, "The Place of Herodotus in the History of Historiography," in Secondo contributo alla storia degli studi classici (Rome: Ed. di Storia e Letteratura, 1984), 42.

27. Ibid.

28. Anthony Grafton, "The Footnote from de Thou to Ranke," History and Theory 33, no. 4 (1994), 60 . 
knowledge within a single intellect, even as he cognized with greater perspicacity than anyone among his contemporaries the significance of this distinction.

Herodotus did not seek Thucydidian coherence for his varied and internally contradictory material, nor did the antiquarians who followed in his footsteps. Ancient antiquarians were motivated by the insight that the boundaries between past and present were in a state of permanent flux. Thucydides' opening statement that "the character of the events which preceded, whether immediately or in more remote antiquity, owing to the lapse of time cannot be made out with certainty" typifies the trajectory taken by the discipline of history in modernity. ${ }^{29}$ The bifurcation between the two approaches to the past was reflected in nineteenth-century history's preoccupation with events rather than institutions and with political rather than social or structural change. By contrast, antiquarianism, like the social-science disciplines that antiquarian knowledge helped to generate, reconstructed distant pasts through synchronic methods. Anthropology, sociology, economics, and other social sciences were concerned with structural change at the level of institutions rather than with the temporary changes signaled by events on the battlefield or at the negotiating table. In short, antiquarianism was for the longue durée; history was for short-term memory. Antiquarians' interest in the longue durée was of course an interest in the past, but the nature, scope, and purpose of this engagement differed radically from that of the historians.

Momigliano's paradigmatic contrast over the course of his multi-decade inquiry into the sources of the past in modernity was heavily informed by his interest in the divergent receptions of Herodotus the antiquarian and Thucydides the historian..$^{30}$ The antiquarian/historian distinction Momigliano made helped to elucidate how forms of knowledge that are frequently indiscriminately merged with history in the modern sense-the sense that Herodotus could never have envisioned, and to which Thucydides approximated much more closely-were classed as antiquarian by the writers and readers of antiquity.

Additionally, the complex reception in European historiography of Greek antiquity's two major narrators of the past served for Momigliano as a larger lesson about the relations between emergent disciplines, reminding him of the many ways in which it was possible to organize knowledge about the past. The light Momigliano shed on disciplinary history through this reception demonstrated to him the political, epistemic, and metaphysical significance of the choices made by these two different disciplines: antiquarian inquiry, which inevitably foundered on the impossibility of attaining sure knowledge, and history, which was driven by the quest for certainty. As I discuss in greater detail below, Momigliano's emphasis on the quest for certainty that drove antiquarian knowledge derives more from his understanding of early modern antiquarianism than from the form of knowledge espoused by Herodotus, who (unlike Momigliano) was entirely at home with the contingent conditions that shaped his access to other times and places. But this very projection on Momigliano's part demonstrates the

29. Thucydides, History of the Peloponnesian Wars, 1.

30. The Herodotus/Thucydides contrast is drawn out most explicitly in the Sather lectures (Classical Foundations, 29-54). 
elasticity of the antiquarian concept, which in part constitutes its relevance to the modern discipline of history.

Momigliano's intervention is important because he went beyond simply reconstructing a lost historical archive. Momigliano made the antiquarian form of knowledge legible in and for a world haunted by a Foucauldian awareness of the dangers of institutional power, and conscious of the dangerous proximity between scientific positivism and fascism in modernity. This was a world of which Herodotus was innocent even when he laid the framework for the emergence of a future knowledge form. Momigliano was more interested in certainty and less willing to question history's foundational axioms than was Foucault, but both figures were wary, with good reason, of modern technologies of power, and of the state's tendency to manipulate historical truth to its advantage. That his parents and extended family were exterminated in Auschwitz certainly imparted a particular poignancy to Momigliano's engagement with history, and may also have intensified his search for an alternative to his chosen vocation in antiquarian ways of confronting, and mourning, the past. ${ }^{31}$

\section{ANTIQUARIANISM AND MODERNITY}

As he was particularly keen to point out in his later work, Momigliano's genealogy of antiquarian knowledge leads from antiquarianism to the social sciences, in particular sociology and anthropology. In an age before history was institutionalized as a subject of instruction in the academy - an event Momigliano dates to the establishment of the first chair in ancient history at Oxford in $1622^{32}-$ or tied to an archive, antiquarian research was characterized by an empirical depth unmatched by the research undertaken in university contexts. Antiquarians engaged nonliterary evidence, and excavated the material culture that later became archeology's provenance. Some titles that exhibit these tendencies include M. Baudelot de Dairval's De L'Utilité des Voyages et de L'Avantage que la recherche des Antiquitez procure aux Sçavans (1698), Edmund Chishull's Antiquitates Asiaticae (1728), Stuart and Revett's The Antiquities of Athens (1762), and Winckelmann's Geschichte der Kunst des Alterthums (1764).

A further paradox of Momigliano's historian/antiquarian distinction is that the antiquarian method was more informed by archival research than was the historical method. In this respect if in no others, modern historians such as Ranke inherited premodern antiquarian methods, even as they purged their discipline of other antiquarian heterodoxies. In Momigliano's genealogy of the disciplines, the archive was "discovered" by the antiquarian rather than the historian. Momigliano illustrates his argument through the example of Edward Gibbon, who, soon after leaving Oxford, began his real inauguration into antiquarian inquiry by "spending twenty pounds on the twenty volumes of the Memoirs of the Academy

31. For Momigliano's dedication to his deceased mother, and the most explicit allusion to the Shoah in his entire oeuvre, see Momigliano, Alien Wisdom, vi.

32. Momigliano, "The Introduction of History as an Academic Subject and its Implications," in Ottavo contributo (Rome: Storia e Letteratura, 1987), 161-178. 
of Inscriptions." 33 Through the introduction to antiquarian knowledge afforded by these epigraphic collections, after having realized that the type of historical inquiry inculcated by the university curriculum could not satisfy his deepest dreams, Gibbon was reborn as an antiquarian, and went on to write the greatest synthesizing work of historical antiquarianism known to modernity.

When, in his autobiography, Gibbon later reflected on the decline of antiquarian knowledge during his lifetime, the figures he chose to mark this decline, such as Lipsius and Isaac Casaubon, were best known as philologists during their lifetimes. This suggests an unexplored path for antiquarian knowledge that is beyond the scope of this essay but closely related to my engagement with philology's disciplinary history. ${ }^{34}$ "In France," recalled Gibbon, "to which my ideas were confined, the learning and language of Greece and Rome were neglected by a philosophic age." ${ }^{35}$ As a consequence of this downgrading of philological knowledge, antiquarian institutions such as the Académie des Inscriptions were "degraded to the lowest rank among the three royal societies of Paris: the new appellation of Erudits was contemptuously applied to the successors of Lipsius and Casaubon." ${ }^{36}$ To be an érudit was to be the opposite of a historian, which, in the Age of the Enlightenment, meant being passé.

In Momigliano's accounting, historical research before modernity was based primarily on textual documentation rather than on archival reconstruction, which was the antiquarian's domain. Histories aimed to reconstruct precise sequences of events chronologically, whereas antiquarians harbored other, temporally more expansive, ambitions. Alongside their methodological divergences, the historian's subject matter differed from that of the antiquarian. Unlike antiquarianism, which dealt in archival minutiae, history dealt in military conquests and defeats and diplomacy between states.

Momigliano's student Anthony Grafton has pursued his teacher's insight concerning the antiquarian origins of the modern historian's archive. Grafton has documented over the course of numerous works that the valorization of the archive inaugurated in the early nineteenth century by Leopold von Ranke represents a break with pre-Rankean historiography. ${ }^{37}$ Antiquarianism from the sixteenth century onwards nonetheless incorporated into itself a specifically early modern variation on "archive fever." The rapture expressed by the seventeenthcentury Orientalist Athanasius Kircher is a case in point, leading his biographer to ask whether "anyone before Leopold van Ranke" had ever expressed "the

33. Momigliano, “Ancient History and the Antiquarian,” 285.

34. I refer to my book-in-progress, "Philology's Contingent Genealogies," which reads the oeuvres of Varro, Vico, Benjamin, Momigliano, and Jacob Bernays as part of a broader conversation about philology's disciplinary history.

35. Edward Gibbon, Memoirs of the Life of Edward Gibbon (London: Methuen, 1900), 123; Momigliano, "Ancient History and the Antiquarian," 308.

36. Gibbon, Memoirs, 308. For Casaubon's method, see Benedetto Bravo, "Critice in the Sixteenth and Seventeenth Centuries and the Rise of the Notion of Historical Criticism," in History of Scholarship: A Selection of Papers from the Seminar on the History of Scholarship Held Annually at the Warburg Institute (Oxford: Oxford University Press, 2006), 162-171.

37. In addition to Grafton, "The Footnote from De Thou to Ranke," see the book-length version of this argument: The Footnote: A Curious History (Cambridge, MA: Harvard University Press, 1999), 34-121. 
dusty pleasures of archival research with so much visceral pleasure." Kircher's antiquarian enthusiasm for the archives radiates from the following passage from the introduction to his Oedipus Aegyptiacus (Egyptian Oedipus, 1652-1655):

I consider there to be ... no art so thoroughly extinct or lost, of which no vestige glimmers in some corner of the world unknown to us, or in some foreign library buried under the covering of a foreign language ... or which, broken up and dispersed in many pieces by the neglect of time, may not be discovered scattered among the ancient authors ${ }^{38}$

Everything is retrievable, suggests Kircher, through the antiquarian method. Given the archival resources at the antiquarian's disposal, and the capacity of the emergent science of philology to reconstruct this lost history, early modern antiquarians subscribe to the belief that nothing is permanently lost to time. The intellectual pursuits cultivated by Kircher and his colleagues diverged from those cultivated by their better-patronized historians whose material was easier to access, more within the mainstream of already-extant knowledge, and less altered by the passage of time.

First in antiquity and later in early modernity, antiquarians embraced raw and internally chaotic material that seasoned historians could not accept without seeking to restructure the detritus of the past into meaningful wholes. Whereas the antiquarian's archive consisted of epigraphic inscriptions in obscure and sometimes as-yet-to be deciphered languages (consider antiquarians' attraction to Egyptian, Chaldean, Syriac, and other languages that were barely known, if at all, to the university curriculum), the historian's literary material had already been varnished by predecessors, who had effectively eliminated any internal inconsistencies.

Momigliano acknowledged history's heavy rhetorical debt to literary genres and styles, even though he was uncomfortable with the way that theorists of historiographical inquiry, such as Hayden White, used this debt to support their arguments for the tropological status of historical knowledge. ${ }^{39}$ Equally important and less studied is the inverse of this debt: the emergence of antiquarianism from nonliterary evidence, including coins, inscriptions, and other material remnants and ruins that could not be accommodated within the canons of proper literary style. Early modern antiquarianism was literary in that it too cultivated a new form of knowledge. At the same time, compared to the historiographical writing of its era, the early modern antiquarian imagination, calibrated to the unstructured chaos of modern life, worked less easily within the canons of recognized literary forms. As Walter Benjamin has famously documented, early modern antiquarianism's basic object of analysis was the fragment, and its basic vocation was manifested in the collector, who detaches "the object from its functional relations" as he goes about assembling his archive. ${ }^{40}$

38. Translated in Daniel Stolzenberg, Egyptian Oedipus: Athanasius Kircher and the Secrets of Antiquity (Chicago: University of Chicago Press, 2013), 178.

39. For further on the Momigliano-White debate, see Momigliano, "The Rhetoric of History and the History of Rhetoric: On Hayden White's Tropes," in Comparative Criticism: A Yearbook, ed. E. S. Shaffer (Cambridge, UK: Cambridge University Press, 1981), III, 259-268 (and n. 13).

40. Walter Benjamin, The Arcades Project, transl. Howard Eiland and Kevin McLaughlin (Cambridge, MA: Harvard University Press, 1999), 207. For more extended reflection, see Benjamin's Ursprung des deutschen Trauerspiels (Berlin: Ernst Rowohlt, 1928). For further kinships between Momigliano and Benjamin, see Miller, "Momigliano, Benjamin, and Antiquarianism." 
Momigliano attributed the decline of antiquarianism in part to the way in which history after Gibbon and Mommsen learned to incorporate antiquarian methodologies and to recognize the value of nonliterary evidence (including epigraphy, coins, and ruins) and to distinguish between primary and secondary sources. ${ }^{41}$ By incorporating synchrony into itself, history transformed and extended its disciplinary identity. Yet these important insights do not tell the full story of antiquarianism's itinerary or of its relevance to contemporary historiographical inquiry. Most important, they do not tell us what happened to antiquarianism after "history became a way of seeing how the world was formed, how man came about, what religion and morality were," and even came to eclipse other ways of reading the past. ${ }^{42}$

Once history became what Momigliano calls "a complicated substitute for revelation" in the nineteenth century, was there any work left for antiquarianism, or for its distant cousin, philology? Momigliano knew that antiquarianism was concerned with more than the mindless collection of data, that it was possessed of a unique disciplinary logic that could not be subsumed (even when it was assimilated) by history. As a historian, Momigliano was well aware of the logic specific to the antiquarian mind and its capacity for embracing human contingency. Yet this awareness was never fully reconciled to the oeuvre of a historian whose life task was, in the words of his student Peter Brown, "to maintain truth in historical studies." ${ }^{43}$ A tension was always present in the form of an unresolved question, which may indeed have prevented Momigliano from fully explicating the implications of his history/antiquarian distinction for the future history of disciplinary knowledge.

In other work produced at the Warburg, Momigliano argued that ancient history had lost the role it possessed until the eighteenth century as our primary source of knowledge, not only concerning the past, but also with respect to the future. Momigliano made this point in his study of the German Hellenist Friedrich Creuzer (1771-1858), a scholar known for his idiosyncratic combination of mythography, historiography, and philology influential during his lifetime, but largely forgotten in subsequent centuries. ${ }^{44}$ Like his inaugural study of antiquarian knowledge, Momigliano's article on Creuzer was composed soon after his wartime emigration to England, and thus was conceived at a pivotal juncture in his life. But in the Momiglianian genealogy of modern historiography, Gibbon stands out most prominently as the last historian who, by combining the craft of

41. On the antiquarian distinction between primary and secondary sources, see Momigliano, "Ancient History and the Antiquarian," 286, and Simon Ditchfield, Liturgy, Sanctity and History in Tridentine Italy: Pietro Maria Campi and the Preservation of the Particular (Cambridge, UK: Cambridge University Press, 1995), 12.

42. Momigliano, "The Introduction of History as an Academic Subject and its Implications," 202.

43. Peter Brown, "Remembering Arnaldo," American Scholar 57, no. 2 (1988), 252. Brown notably dedicated one of his best-known works, The Body and Society (New York: Columbia University Press, 1988), to Momigliano's memory.

44. Momigliano, "Friedrich Creuzer and Greek Historiography," Journal of the Warburg and Courtauld Institutes 9 (1946), 152-163. In the wake of Momigliano's work, Creuzer's achievement has attracted more attention. See Josine H. Blok, "Quests for a Scientific Mythology: F. Creuzer and K. O. Müller on History and Myth," History and Theory 33, no. 4 (1994), 26-52, and Stephen N. Larsen, "Friedrich Creuzer and the Study of Antiquity" (PhD diss., Princeton University, 2008). 
the historian with the empirical passions of the antiquarian, was able to generate interpretations of antiquity that made that past indispensable for the future. ${ }^{45} \mathrm{By}$ merging antiquarian methods with history, The Decline and Fall of the Roman Empire (1776-1788) heralded the decline of one discipline, antiquarianism, and its replacement by a newly reconfigured discipline of history that borrowed heavily from the form of knowledge it had replaced, frequently without acknowledgment.

Much of Momigliano's work on the historian/antiquarian relation was published only posthumously. The most provocative discussion of this topic among Momigliano's published works, his Sather lectures, had to wait decades for publication, notwithstanding their considerable impact on the auditors who were lucky enough to hear them delivered at the University of California, Berkeley, in 1962. ${ }^{46}$ Perhaps Momigliano delayed the publication of this magnum opus for so many years because he was overwhelmed by the scope of his project, and challenged by the task of synthesizing it into a coherent whole. That Momigliano was awed by the magnitude of the task he had set himself is suggested by his description, in a 1967 letter to the Marxist philologist Sebastiano Timpanaro, of his life's work as having been preoccupied by three themes: "the influence of Greco-Roman and Jewish historical thought on subsequent generations of historical thought; the organization that ancient political and social structures provided or didn't provide to stabilize peace and to ensure freedom of action and of discussion; [and] the position of Jews and of Jewish civilization [civilità ebraica] in the ancient world and after." ${ }^{\prime 7}$ For Momigliano to have assembled the Sather lectures into publishable form during his lifetime would have meant writing his own epitaph.

With respect to the project that Momigliano lists first among his lifelong preoccupations, of illuminating the impact of Greco-Roman and Jewish historiography on modern historiographical inquiry, he promises Timpanaro that this theme will "stand out more clearly in the still unpublished Sather lectures." Although Momigliano's vision of antiquarianism and its location within the history of the disciplines was elucidated when these lectures were published, the illumination did not arrive until nearly a quarter-century after the promise was made. As the use made here of Foucauldian genealogy is intended to suggest, even though Momigliano's impact on classical and early modern historiography has been substantial and widely acknowledged, Momiglianian antiquarianism still awaits recognition within the theoretically oriented subdisciplines of historical inquiry, including those, such as critical theory, that engage with the philosophy of history without conceiving of themselves as "historical" per se.

45. "Edward Gibbon fuori e dentro la cultura italiana," Studi romani 24 (1976), 9-23; "Gibbon from an Italian Point of View," Daedalus 105, no. 3 (1976), 125-135; "Gibbon's Contribution to Historical Method,” Historia: Zeitschrift für Alte Geschichte 2, no. 4 (1954), 450-463.

46. For the impact of Momigliano's genealogy on John Howland Rowe, a historian of anthropology's origins who was a professor at Berkeley when Momigliano delivered his lectures, see his two articles: "The Renaissance Foundations of Anthropology," American Anthropologist n.s. 67 (1965), 1-20, esp. p. 15, n.1, and "Ethnography and Ethnology in the Sixteenth Century," Kroeber Anthropological Society Papers 30 (1964), 1-19.

47. "Il primo interesse dovrebbe apparire più nitidamente nelle Sather Lectres ancora inedite." Cited in Riccardo Di Donato, "Filologia, marxismo, guerre e altro: dal carteggio Momigliano-Timpanaro," La Gazzetta di Pisa 3, no. 7/3 (March 2001), 2-3. 
In addition to obscuring the force of Momigliano's vision, the sporadic publication history of Momigliano's disciplinary genealogy has made it difficult to fully assess the lineage the Italian historian postulated leading from Herodotus and Varro to the modern social sciences. Recent scholarship has drawn attention to the visionary aspects of Momigliano's thinking on this topic, thereby giving credence to Peter Miller's argument that Momigliano authorized his genealogy "in such an offhand way, in a publication that appeared so long after most people had formed their impression of his notion of antiquarianism, that its call has not been heard, let alone heeded." ${ }^{48}$ Even as the implications of genealogy for Momigliano's method remain unexamined, the existing scholarship on Momiglianian antiquarianism has also not yet come to terms with the fragmentary status of Momigliano's publications on this subject. For a topic so central to his life's work, the slow pace of this highly productive scholar's writings on antiquarianism is somewhat unusual. Momigliano never systematized his genealogy of the disciplines in a scholarly monograph or other comprehensive study. Archival research, of the sort underway at Pisa-based Archivio Arnaldo Momigliano, will surely shed more light on Momigliano's contributions to the history of antiquarian knowledge. ${ }^{49}$ But a full reconstruction will need to go beyond examining Momigliano's own statements, published and unpublished, and engage with the primary sources on which the greatest modern historian of ancient historical knowledge based his morphology of disciplinary knowledge. We will need, in short, to adopt a Foucauldian perspective on the oeuvre generated by this theorist of modern knowledge forms.

Like a latter-day antiquarian, Momigliano violates many conventions of modern academic historiography. He melds past and present with seemingly effortless grace. As if channeling Herodotus into his writing style, Momigliano inserts his historical self into the historian's narrative. Also like Herodotus, Momigliano resists, sometimes vociferously, attempts to reduce history to mere assemblages of dates and names. He prefers instead to emphasize biography. One of the best treatments of Momigliano's method, by G. W. Bowersock, is tellingly entitled "Momigliano's Quest for the Person." ${ }^{50}$ As Peter Brown accurately noted, Momigliano distinguished himself from his immediate predecessors in the field of the study of Roman antiquity, Mikhail Rostovtzeff, Ronald Syme, and Hugo Jones, because "he felt that they overlooked that all-important residuum of human

48. Peter N. Miller, "Introduction: Momigliano, Antiquarianism, and the Cultural Sciences," in Miller, ed., Momigliano and Antiquarianism, 52. Among other recent considerations of Momigliano's genealogy, the work of Mark Salber Phillips is noteworthy. See his "Reconsiderations on History and Antiquarianism: Arnaldo Momigliano and the Historiography of Eighteenth-Century Britain," Journal of the History of Ideas 57, no. 2 (1996), 297-316.

49. As the recently published catalog of Momigliano's Pisa archive indicates, vast quantities of Momigliano's writings and correspondence still await publication. See Giovanna Granata, L'Archivio Arnaldo Momigliano: Inventario Analitico (Rome: Edizioni di Storia e Letteratura, 2006). Further unpublished work may be expected from the tenth contributo (in preparation for publication, according to the statement of Riccardo Di Donato, in Miller, ed., Momigliano and Antiquarianism, 68) and Peace and Liberty in the Ancient World: The Cambridge Lectures 1940 (Cambridge, UK: Cambridge University Press, forthcoming).

50. G. W. Bowersock, "Momigliano's Quest for the Person," in The Presence of the Historian: Essays in Memory of Arnaldo Momigliano, History and Theory, Beiheft 30 (1991), 27-36. 
motivation." ${ }^{51}$ When we conceive of Momigliano as a historian whose antiquarian predilections prevent him from erasing his own historicity from his narratives, we are in a better position to understand how the antiquarian method, when applied to modern historiography, can obliterate the distance that conditions and constitutes modern historical inquiry and that lies at the very foundation of historical objectivity. ${ }^{52}$ In Momigliano's perception, the tension between history and the antiquarian imagination gives rise to new knowledge, and not merely to the destruction of old methodologies.

Scholars prior to Momigliano had noted that ancient $\alpha \varrho \chi \alpha ı \lambda o \gamma i ́ \alpha$ (archeology) as a discipline was preeminently concerned with "the genealogies of heroes and men and the early foundations of cities." 53 But Momigliano's read-

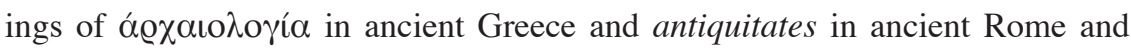
medieval Europe imparted to an ongoing inquiry a conceptual coherence that, for the first time in modern disciplinary history, could forcefully transform an entire discipline. Antiquarian knowledge as narrated through the Momiglianian prism is crucial to any genealogy of the disciplines, including the Foucauldian one, inasmuch as, more than any other discipline, antiquarianism foregrounds the forms of knowledge history traditionally excluded from its purview. Taking account of epigraphy, numismatics, and other nonliterary artifacts that enter the historiographical record by way of temporal difference (diachrony) rather than through filiation and narrative interest (synchrony), antiquarianism is in potentia a critique of actually existing historiography. It is an argument in favor of the fragment, an appeal to uncertainty, an argument that discerns agency, and hence freedom, not in the ability of retrospective interpreters to ascertain the facts beyond a doubt, but in the ability of archival excavations to instill wonder and awe in those who make their findings lucid to the world..$^{54}$

Wonder and awe are of course inevitably accompanied by doubt, and herein lies the Achilles' heel of Momiglianian genealogy. For even if it were true that early modern antiquarians "could justly congratulate themselves that the quality and quantity of the documents they used conferred on the knowledge of the past a greater certainty than that extracted from literary sources" in their methodological drive for "greater certainty," early modern antiquarians were by no means carrying on the traditions pioneered by their ancient predecessors, who were more concerned with instilling doubt than with establishing certainty. ${ }^{55}$ Herodotus's invocation of the words of Solon, king of Athens, to the Lydian king Croesus, is instructive in this regard. When asked by the arrogant Lydian king to ratify his

51. Brown, "Remembering Arnaldo," 252.

52. For a stimulating consideration of distance as a normative aspect of post-Romanticist historiography, see, among others, Mark Philips, "Relocating Inwardness: Historical Distance and the Transition from Enlightenment to Romantic Historiography," PMLA 118 (2003), 436-449.

53. Eduard Norden, Agnostos Theos: Untersuchungen zur Formengeschichte religiöser Rede (Stuttgart: Teubner, 1956), 372.

54. Compare Walter Benjamin on a story told by Herodotus in his essay on the storyteller: "This story from ancient Egypt [by Herodotus] is still capable of arousing astonishment [Staunen] and thoughtfulness [Nachdenken]" (Benjamin, "Der Erzähler," Gesammelte Schriften-Werkausgabe [Frankfurt: Suhrkamp, 1980], 445-446).

55. Riccardo Di Donato, "Momigliano from Antiquarianism to Cultural History," in Miller, ed., Momigliano and Antiquarianism, 75. 
belief that he was the happiest man in the world, Solon replies in an instructively contrarian fashion that indexes the importance Herodotus places on uncertainty as a condition of intellectual inquiry. "Croesus," says Solon, "human life is pure chance. You seem to be very wealthy, and you rule over many people, but I cannot yet tell you the answer you asked for until I learn how you ended your life" (1.32.4-5). On encountering these strategically situated lines, the reader is confronted with this ancient antiquarian's epistemic goal. As indicated in Solon's advice to Croesus, this agenda was more interested in instilling doubt, of reminding readers and listeners of the contingent conditions through which their knowledge about the past is constituted, than in establishing certainty.

Indeed, had he been able to witness the life taken by the discipline he helped to found, Herodotus would likely have criticized the modern historical quest for fetishizing certainty. Momigliano endorsed modern historiography's sanctification of certainty, and sought to buttress it through the application of antiquarian methods to historical inquiry. For Herodotus, the quest for certainty would have signified inexcusable hubris on a par with Xerxes' refusal to heed Artobanus's advice against waging war on the Athenians, an act that ultimately brought about the defeat of the Persian empire $(7.10 .3 ; 7.50 .2)$. Hence, at least with respect to the most important antiquarian of ancient Greece, it needs to be acknowledged, pace Momigliano, that the alignment between antiquarianism and the quest for certainty is not internally consistent, unless the impossibility of knowing can be regarded as a form of certainty in its own right, and methodological inquiry can be structured according to this insight.

Because he so closely aligned himself with the historical quest for certainty (while distancing himself from, or simply refusing to recognize, the antiquarian cultivation of doubt), Momigliano never fully cognized the disjuncture between ancient antiquarians' embrace of contingency and early modern antiquarians' quest for certain knowledge. At the same time, Momigliano did go some distance toward recognizing the hermeneutical-and not merely the historical or archival-value of antiquarian knowledge, even when he focused on early modern antiquarianism. In the groundbreaking 1950 article that launched a new subfield of inquiry, Momigliano wrote that early modern antiquarians revealed "how to use non-literary evidence, but they also made people reflect on the difference between collecting facts and interpreting facts." ${ }^{56}$ By increasing the scope for interpretation in engaging with the past, early modern antiquarians constituted themselves as true heirs to the Herodotian emphasis on doubt.

Given Momigliano's abiding interest in history as a means of establishing truth, it goes without saying that the foregoing attempt to vindicate Momigliano's conception of antiquarian knowledge as a form of negative historical inquiry, and as a destruction of certain kinds of historical certainties, requires reading Momigliano the historian against the grain (an activity perhaps more attractive to a scholar of literature, such as myself, than to scholars with other disciplinary affiliations). At the same time, Momigliano's occasional revelations of his anti-

56. Momigliano, "Ancient History and the Antiquarian," 286. See also on this aspect of Momigliano's methodology, Karl Christ, "Arnaldo Momigliano and the History of Historiography," History and Theory, Beiheft 30 (1991), 5-12. 
quarian self, particularly in his autobiographical writings, as well as his frequently articulated kinship for the renegade antiquarians from Herodotus to Foucault who have haunted the modern historiographical project, suggest that this contradictory intellectual might not have found such a contrarian reading of his oeuvre entirely alien. Momigliano's insights concerning the attractions of antiquarian knowledge in a post-historical age - an age that looks on positivism with increasing skepticism, and that is likely to find more use in the varieties of doubt and contingency than in mirages of certainty - add further substance to such a reading.

Throughout his voluminous oeuvre, Momigliano explored and also modified the proposition he first advanced in 1950 that the modern social sciences originated in the ancient antiquarianism of Herodotus, Dionysus of Halicarnassus, and Varro. According to Momigliano's trajectory, antiquarianism breathed its last in response to the so-called Pyrrhonist crisis of the sixteenth to eighteenth centuries, when, due in part to Descartes and Bacon, the possibility of attaining certain knowledge was permanently called into question. ${ }^{57}$ Culminating in Hume, this new movement derived from Sextus Empiricus, a Hellenistic philosopher whom the major historian of modern skepticism, Richard Popkin, has labeled "obscure and unoriginal" although even by Popkin's assessment Sextus had a "dramatic role in the formation of modern thought." 58

The antiquarian response to the new Empiricism asserted the value and indeed the necessity of certain knowledge based on the resources of material culture. Numismatics, archeology, textual criticism, and other synchronic methodologies were all either invented or revived during the early modern period, on the basis of ancient collections of epigraphy and other forms of material culture. In spite, or perhaps precisely because, of their dependence on their antiquarian predecessors, Joseph Justus Scaliger (c. 1609) and Giambattista Vico (d. 1744) radically revised ancient precedents. ${ }^{59}$ Their revisions were accomplished through feats of hermeneutical exegesis, in Vico's case of Roman law, in Scaliger's case of ancient chronology. ${ }^{60}$ As much as separates the agendas of Herodotus, Varro, Vico, Scaliger, and other major early modern antiquarians who have gone unmentioned here, such as Mabillon (d. 1707) and Montfaucon (d. 1741), Momiglianian antiquarianism, in the revisionary account I have presented here, accommodates, and is enriched by, them all.

\section{ANTIQUARIANISM AS GLOBAL KNOWLEDGE FORM}

Although attention to the antiquarianisms of Europe and Greek antiquity has occupied the bulk of this essay, Asian and Islamicate antiquarianisms have as

57. For an alternative periodization (which questions Momigliano's account), see Markus Völkel, "Pyrrhonismus historicus" und "fides historica": die Entwicklung der deutschen historischen Methodologie unter dem Gesichtspunkt der historischen Skepsis (Frankfurt: Lang, 1987), 342-344.

58. Richard H. Popkin, History of Scepticism from Erasmus to Spinoza (Berkeley: University of California Press, 1979), 19.

59. Scaliger's most immediate predecessor in this regard was Crates of Mallon; Vico's predecessors were Varro and Augustine. The debates among these figures, internal to the field of antiquarian philology, are discussed in Philology's Contingent Genealogies (see n. 33 above).

60 . Worth noting with respect to the ancient/early modern antiquarian connection is $M$. Terenti Varronis Opera cum notis J. Scaligeri (Paris: A. Turnebi, 1585). 
much to contribute to our conceptualization of antiquarian knowledge as to the emergent critique of modern historical knowledge forms. Non-European antiquarianisms have been as revolutionary in their own milieus as Herodotus's insistence on doubt and the early modern antiquarian quest for certainty were within their respective worlds. ${ }^{61}$ In disciplinary terms, antiquarianism extends the very meaning and purpose of historical inquiry, by extending the range of legitimate sources, changing the questions that can be posed of material from the past, and shifting the terms according to which the answers are evaluated. In contemporary terms, antiquarianism gives life to the ancient vocation of criticism, which, more in eras past than in times present, has at its most powerful been both historically and philologically inflected. ${ }^{62}$ None of these functions can reasonably be restricted to any single geography.

Once we grasp the mutual debts of antiquarianism and criticism in terms of Momigliano's disciplinary trajectory, antiquarianism's potential to realize itself in contemporary contexts will be unleashed. Friedrich Nietzsche famously warned that antiquarianism can be reduced to "a blind mania for collecting [Sammelwut], a restless compiling of everything that has ever existed." 63 Yet in that very movement toward the antiquarian alternative to history-conceived in modern terms as archival reconstruction driven by a passion for the obscure, the forgotten, the oppressed, and the otherwise unassimilated-another form of knowledge stands revealed. The bricoleur figure put forward by French anthropologist Claude LéviStrauss shares with Momigliano's antiquarian, Foucault's genealogist, and Benjamin's collector a special relationship to mythical thought as well as a particular methodology. Most congruently with the ways of knowing cultivated by antiquarians, the bricoleur goes about his work of assembling into systems the fragments that cross his path without taking account of the "availability of raw materials and tools conceived and procured for the purposes of a project." ${ }^{64}$

A defining characteristic of the bricoleur's methodology is thus that, because his knowledge is constituted from fragments, it is uniquely capable of transcending the time-space coordinates within which it is generated. In my view, this peculiarity goes some distance toward explaining why antiquarian knowledge is better suited to understanding the diversity of world culture, and more adept at dealing with cultural difference, than are the more conservative strains of historical knowledge. The Herodotus/Thucydides contrast that has structured this essay, and that structured much of Momigliano's work, is an obvious illustration of the global

61. Modern scholarship of Asian antiquarianism, particularly that which takes account of Momigliano's intervention, is still in its infancy. The most important recent contribution to this emerging field of inquiry is Antiquarianism and Intellectual Life in Europe and China, 1500-1800, ed. Peter N. Miller and François Louis (Ann Arbor: University of Michigan Press, 2012). See also Tamara Chin, "Antiquarian as Ethnographer: Han Ethnicity in Early China Studies," in Critical Han Studies: The History, Representation, and Identity of China's Majority, ed. Thomas Mullaney et al. (Berkeley: University of California Press, 2012).

62. For a brilliant account of the emergence of the concept of criticism in relation to antiquarianism (here in the guise of philology) and history, see Bravo, "Critice in the Sixteenth and Seventeenth Centuries and the Rise of the Notion of Historical Criticism."

63. Friedrich Nietzsche, Werke in drei Bänden, ed. Karl Schlechta (Munich: Carl Hanser Verlag, 1954), I, 228.

64. Claude Lévi-Strauss, The Savage Mind (Chicago: University of Chicago Press, 1966), 17. 
scope of antiquarian knowledge, given Herodotus's unchallenged reputation as the most globally attuned writer of Greek antiquity as compared to Thucydides' comparative lack of interest in non-Greek civilizations, but there are others.

When Momigliano wrote as a historian, he wrote of ancient Rome, Greece, early modern Europe: subjects that were close to home. When Momigliano wrote as an antiquarian, he wrote of the strange and unfamiliar, of that which was, by definition, impossible to know. The comparative globality of the antiquarian imagination when juxtaposed to the comparative provincialism of the historical imagination helps to clarify antiquarianism's contribution to the synchronically organized comparative social sciences, and in particular to the discipline of anthropology, which has been and continues to be more global in scope than mainstream historiography. (History is arguably the most diverse discipline within the humanities, encompassing nearly all geographies and all ways of knowing, but the point here is simply that the dominant modes of knowing within mainstream historiography are not generally informed by non-European archives.) Herodotus is of course also claimed by the discipline of anthropology, and often with the same enthusiasm that he is assimilated into the canon of history's history.$^{65}$

Momigliano himself compellingly exemplifies the global outlook facilitated by antiquarian knowledge, for one of the most underappreciated aspects of his intellectual achievements is his deep reading in and knowledge of non-European traditions, which enabled Momigliano to generate profound (if brief) comparative accounts of global historical knowledge.$^{66}$ During those rare but priceless moments in his oeuvre when Momigliano engaged in comparative reflections on global historiography, the results were striking. Rather than posit the GrecoRoman or European historiographical tradition as the absolute-although he might have been expected to do so, given that these were the areas of his primary expertise-Momigliano consistently viewed Asian and Islamic historiographical traditions on their own terms. In "Tradition and the Classical Historian" (1972), Momigliano invoked classical Islamic, Chinese, and Danish historiography to tell us not how they fell short of the Greco-Roman tradition, but to indicate with greater precision the various qualities that the Greco-Roman tradition lacked ${ }^{67}$

When Momigliano ponders the problem that has often bedeviled Indologists, and that was famously flagged by Hegel in his lectures on the philosophy of history, concerning the lack of a robust historiographical tradition in premodern India (aside from Islamic historiographies composed primarily in Persian), his comments reflect the antiquarian tendency to understand cultural and historical difference pluralistically, in terms of their own time and place, to approach the seemingly anomalous with humility, and to refrain from engaging in grandiose absolutist and essentialist claims about civilizational difference of the kind that

65. See, for example, James Redfield, "Herodotus the Tourist," Classical Philology 80, no. 2 (1985), 97-118. Redfield incidentally thanks Momigliano for his comments on this essay in his introductory note (p. 97).

66. Grafton alludes to Momigliano's reading of classical Chinese historiography in "Arnaldo Momigliano: A Pupil's Notes," American Scholar 60, no. 2 (1991), 238.

67. Arnaldo Momigliano, "Tradition and the Classical Historian," History and Theory 11, no. 3 (1972), 284. 
the more prolific nineteenth-century historians used to buttress their methodologies. Resisting all of these temptations to which many of his fellow historians succumbed (not least among them Hegel, when he wrote in a self-consciously historicist mode), Momigliano reflects with astonishing accuracy on this problem of the absence of an indigenous historiographical tradition in Indian history, considering how far the subject lies from his actual expertise. "The poverty of Indian historiography," Momigliano writes, "must be judged with reference to a world in which normally history counted far less than it counts now: indeed history, rather than determining the character of civilization, was normally inferior to religion, rhetoric, poetry, philosophy, and derived its values from them." 68

Momigliano's methodological response to the problem of the supposed "absence" of Indian history presumes no deep erudition concerning Indian knowledge systems. ${ }^{69}$ It does, however, presume a brilliantly sophisticated framework for engaging in global comparison. The much more common historiographical move (and the one to which, as noted, Hegel succumbed) would have been to present European modernity, when historical discourse was naturalized as a condition for civilizational attainment, as the comparative norm, and to find all civilizations that fell short of this standard to be lacking. Instead of pursuing this conventional path, Momigliano defamiliarizes Europe. He makes strange the world that would make the existence of a robust historiographical tradition into a norm. Such is the antiquarian imagination in action. Some theorists of historical knowledge would argue that such acts of defamiliarization are cultivated by history in general, without presuming any debt to antiquarian inquiry. I would argue to the contrary that history is only favorable to defamiliarization when it is enriched by the antiquarian method, and that all too frequently historians neglect the substantial benefits conferred on their discipline by antiquarian knowledge. The failure of many historians to live up to the broad-minded norms exemplified by Herodotus, Foucault, and Momigliano is largely a function of history's suppression of antiquarian knowledge in consequence of its quest for absolute truth.

Momigliano would of course have disagreed with some of the assessments offered here, particularly with respect to his own work. He would have insisted that it was the antiquarians who, even more than the historians, made possible the pursuit of certain knowledge about the events of times past, and, further, that the search for truth necessarily figures into any ethically grounded engagement with the past. These divergences are not matters that can be easily, or even fruitfully, resolved. Rather than seeking to clarify the status of truth in Momigliano's historiography, which many commentators have shown to be central to his intellectual agenda, I have sought to highlight the importance of doubt, a value that in my view permeates Momigliano's work, if less explicitly than the concern for truth, and that is aligned with his profoundly philosophical awareness of the contingency of human knowledge.

68. Arnaldo Momigliano, "Remarks on Eastern History Writing," in Terzo contributo alla storia degli studi classici e del mondo antico (Rome: Ed. di Storia e Letteratura, 1966), 236.

69. The most compelling recent engagement with this problem from the perspective of South Asian studies is Ranajit Guha, History at the Limit of World-History (New York: Columbia University Press, 2003). 
Momigliano's writings do not suggest any extensive conscious engagement with doubt, certainly not with the same intensity as can be observed in Herodotus (see, for example, 7.54.3), or in other, later products of the antiquarian imagination. Yet one of Momigliano's most influential students, the classicist Peter Brown, who consistently describes himself as a historian (rather than an antiquarian), nonetheless has articulated the purpose of historical knowledge in ways that strikingly resemble his teacher's methodological humility, and that evoke Momigliano's ability to empathize with the unknown, the distant, and the foreign. Reflecting on the benefits of historicizing one's own self, Brown writes, "A little history ... counters the amiable tendency of learned persons to think of themselves as if they were hang-gliders, hovering silently and with Olympian ease above their field." ${ }^{\text {70 }}$ In Brown's view, one purpose of history, and particularly histories of our selves, is to teach us that "we are in no way different from the historical figures whom we study in the distant past: we are embodied human beings caught in the unrelenting particularity of space and time." The unrelenting particularity of space and time, of human contingency, human freedom, and the eternal recurrence of doubt, is the domain of antiquarian knowledge.

From the point of view of disciplinary critique, and of the disciplinary genealogies on which Momigliano and Foucault were embarked, the value of antiquarianism lies less in its actual yield than in the paths it forges for new forms of intellectual inquiry. Antiquarianism enables the persistent critique of history. It helps us read history against itself. It considers events, people, places, and things in their singularity, as fragments that may or may not cohere into a whole. In chronicling in Foucauldian fashion the normativity of institutions, and in refusing to treat them as immune to the vagaries of power, it offers ways of thinking outside bureaucratic structures, such as the state. Antiquarian inquiry enables material to transform method, and trains humanists and social scientists alike to confront the epistemic consequences of human contingency, even as they seek to reconcile the need for certainty with the ethical advantages of doubt.

Rather than positing the perfectibility of the human intellect, antiquarianism recognizes what is not knowable. Frequently, scientifically oriented disciplines in their more positivist phases militate against the humility cultivated by Momigliano and Brown. As perhaps the last great historian to traverse the disparate domains of antiquarianism and history with equal grace, Momigliano's vision enables scholars to reclaim antiquarianism as their rightful vocation among the diversity of humanistic knowledge forms. Momigliano's antiquarian genealogy, like his genealogical antiquarianism, helps those of us concerned with the future of the past and the history of the present to insure that our quests for certain knowledge never lose sight of the contingency of all things human.

\section{Yale-NUS College}

Singapore

70. Peter Brown, A Life of Learning (New York: American Council of Learned Societies, 2003), 6 for this and the following quotation. 